\title{
Pemanfaatan Sampah Rumah Tangga Menjadi Beberapa Jenis Pupuk Cair MOL (Mikro Organisme Lokal) di Desa Pudak Kecamatan Kumpeh Ulu Kabupaten Muara Jambi
}

\author{
Rainiyati ${ }^{1}$, Ahmad Riduan², Zulkarnain², Eliyanti², Sarah Fiebrina Heraningsih ${ }^{2}$ \\ 1,2 Universitas Jambi
}

\begin{abstract}
Article History ABSTRACT
Received 11.09.2019

Received in revised form

26.11.2019

Accepted 02.12.2019

Available online 20.12.2019

THE PROCESSING OF HOUSEHOLD WASTE INTO VARIOUS TYPES OF LOCAL MICRO ORGANISMS (LMO) LIQUID FERTILIZERS IN PUDAK VILLAGE, KUMPEH ULU DISTRICT, MUARO JAMBI REGENCY. Household waste such as leftover rice and vegetables can be used as a major component in producing Local Micro Organism (LMO). Local Micro Organism has many advantages, including being used as liquid organic fertilizer, as a decomposer in compost processing, as well as being used as bio-pesticides. The purpose of this community service project was to help the people, particularly farmers, in Pudak Village in producing LMO liquid fertilizer by providing them with relevant knowledge and technology. The technology was developed by utilizing of leftover rice and vegetables which are normally treated as unwanted household wastes. This LMO liquid fertilizer is very much needed by farmers to increase their farm output since it was proven to be able to improve plant growth and development, which in turn increase farm production eventually. In addition, this liquid fertilizer can also be sold and resulting in additional income for farmer household, and village community in general. Finally, as is stated in the objective, this community service program has produced output in the form of LMO liquid fertilizer, which then can be applied on farmers' field.
\end{abstract}

KEYWORDS: Household Waste, Local Micro Organism, Organic Farming, Organic Fertilizer, Sustainable Agriculture.

\section{PENDAHULUAN}

Desa Pudak terletak di bagian Selatan Kabupaten Muaro Jambi, berada di Kecamatan Kumpeh Ulu Kabupaten Muaro Jambi dengan jarak ke ibukota kabupaten \pm $48 \mathrm{~km}$ dan hanya $\pm 10 \mathrm{~km}$ dari Kota Jambi (Muaro Jambi dalam angka, 2012). Luas wilayah Desa Pudak adalah 1600 ha dengan batas wilayah sebagai berikut: sebelah Timur

\footnotetext{
${ }^{1}$ Corresponding author: Fakultas Pertanian Universitas Jambi. Jl. Lintas Sumatera Jl. Jambi - Muara Bulian No.Km. 15, Mendalo Darat, Kec.
} Jambi Luar Kota, Kabupaten Muaro Jambi, Jambi 36122, Indonesia. Email: rainiyatiyusuf@yahoo.co.id 
berbatasan dengan Desa Muara Pudak dan Talang Duku; sebelah Utara dengan Desa Kemingking; sebelah Selatan dengan Desa Kasang Pudak dan Kasang Kota Arang; dan sebelah Barat dengan Desa Kota Karang dan Kasang Lopak Alai. Dari luasan wilayah Desa Pudak tersebut $\pm 994,48$ hektar terdiri dari tanah sawah, tanah pekarangan \pm 9 hektar, dan tanah perkebunan $\pm 596,52$ hektar (RPJM Desa Pudak, 2012).

Jumlah penduduk di Desa Pudak lebih kurang 4.271 jiwa yang didominasi oleh kelompok umur produktif 16-36 tahun adalah 1.393 jiwa. Berdasarkan tingkat pendidikan kebanyakan masyarakat tidak sekolah dan putus sekolah adalah 33,6\%, tamat SD 29.0\%, tamat SMP 25,1\%, tamat SMA 20,7\%, tamat Perguruan Tinggi hanya 2,94\%. Mata pencaharian penduduk desa $27,8 \%$ petani, peternakan $9,86 \%$, petani kolam $3,67 \%$, tidak bekerja $19,6 \%$.

Sarana dan prasarana infrastruktur yang dimiliki antara lain transportasi darat, informasi dan komunikasi, air bersih, peribadatan, pendidikan, kesehatan, penerangan, dan perekonomian. Penduduk umumnya berasal dari kultur Jawa dengan mayoritas usaha di bidang pertanian tanaman pangan padi, hortikultura dan perkebunan (sawit).

Prasarana jalan yang menghubungkan desa Pudak dengan ibukota Kabupaten dan desa-desa lain di sekitarnya dalam kondisi cukup baik sehingga mobilitas penduduk relatif lancar. Prasarana irigasi teknis belum tersedia, pengairan untuk lahan sawah sepenuhnya bersifat tadah hujan. Sarana dan prasarana yang terkait dengan usaha tani yang tersedia antara lain kelompok tani, dengan beberapa kelompok telah berkembang dengan baik.

Potensi luas lahan yang cukup tersedia, ditambah dengan kultur masyarakat yang telah terbiasa sebagai petani $(27,8 \%)$ maka diharapkan akan lebih mudah mengadopsi teknologi pertanian organik sebagai salah satu alternatif usaha pertanian yang ramah lingkungan dengan mengoptimalkan pemanfaatan sumberdaya lokal, sekaligus mampu menekan pengeluaran modal dalam budidaya tanaman dan meminimalkan kerusakan lingkungan (Asandhi, Nurtika, \& Sumarni, 2005).

Sistem pertanian organik adalah sistem produksi holistik dan terpadu, mengoptimalkan kesehatan dan produktivitas agro ekosistem secara alami serta mampu menghasilkan pangan dan serat yang cukup, berkualitas dan berkelanjutan (Sutanto, 2002). Dalam prakteknya, pertanian organik dilakukan dengan cara: (1) Menghindari penggunaan bibit/benih hasil rekayasa genetika, (2) Menghindari penggunaan pestisida kimia sintetis (3) Pengendalian gulma, hama dan penyakit dilakukan dengan cara mekanis, biologis dan rotasi tanaman, (4) Menghindari penggunaan zat pengatur tumbuh dan pupuk kimia sintetis, (5) Kesuburan dan produktivitas tanah ditingkatkan dan dipelihara dengan mengembalikan residu tanaman, pupuk kandang, dan batuan mineral alami, serta penanaman legum dan rotasi tanaman, dan (6) Menghindari penggunaan hormon tumbuh dan bahan aditif sintetis dalam makanan ternak (Deptan, 2002).

Metode yang ditawarkan untuk menyelesaikan permasalahan pada kelompok tani di Desa Pudak Kecamatan Kumpeh Ulu Kabupaten Muaro Jambi adalah "Pemanfaatan sampah rumah tangga menjadi beberapa jenis pupuk cair MOL (Mikro Organisme Lokal)". Sampah rumah tangga yang menjadi target utama sebagai bahan pembuatan pupuk cair MOL juga akan memberikan kontribusi tersendiri bagi mayarakat setempat agar dapat memahami pentingnya menjaga kebersihan lingkungan, terutama dari dampak volusi tumpukan sampah rumah tangga. Sampah rumah tangga yang akan dimanfaatkan 
menjadi MOL dalam program ini adalah sisa nasi, serta sisa buah dan sayuran. Kedua jenis sampah ini paling banyak dan cepat sekali mengalami pembusukan yang pastinya selain mencemari lingkungan sekitar, beraroma tidak sedap juga merupakan sumber berbagai penyakit bagi manusia dan hewan ternak.

Perlunya pemberdayaan petani melalui praktek penerapan pengetahuan cara membuat pupuk organik cair MOL yang berbahan dasar sampah rumah tangga (sampah nasi dan sayuran), akan mampu menjadikan petani lebih mandiri, sekaligus akan mengubah pola pikir masyarakat terkait dampak kerusakan lingkungan, serta memahami terjadinya degradasi lahan pertanian akibat pertanian konvensional yang sangat tergantung kepada pupuk dan pestisida sintetis, sehingga akan memahami pula makna kembali pada sistem pertanian organik yang ramah lingkungan.

Mengingat di desa Pudak merupakan sentra produksi tanaman pangan dan hortikultura yang sangat membutuhkan pupuk organik maka melalui program ini kami mengajak petani untuk memanfaatkan sampah rumah tangga berupa sisa nasi dan sisa sayuran sebagai bahan dasar pembuatan pupuk cair MOL (Mikro Organisme Lokal).

MOL (Mikro Organisme Lokal) adalah larutan hasil fermentasi yang berbahan dasar dari berbagai sumber daya alam yang tersedia dan dapat digunakan sebagai bahan pupuk cair. Pupuk cair MOL selain mengandung unsur hara mikro dan makro, juga mengandung bakteri yang berpotensi sebagai perombak bahan organik, perangsang pertumbuhan, dan sebagai agens pengendali hama dan penyakit tanaman, sehingga MOL dapat digunakan baik sebagai dekomposer, pupuk hayati dan sebagai pestisida organik terutama sebagai fungisida. MOL memiliki banyak kegunaan, diantaranya 1. Dimanfaatkan sebagai POC (Pupuk Organik Cair); 2. sebagai dekomposer atau biang kompos untuk pembuatan kompos; 3. Sebagai pestisida nabati untuk mengendalikan Hama dan Patogen penyebab penyakit pada tanaman.

Selain kandungan unsur hara, kualitas MOL juga ditentukan oleh populasi mikroorganisme berguna yang terdapat di dalam MOL. Bakteri pelarut fosfat dan mikroorganisme selulolitik yang terkandung dalam MOL nasi lebih tinggi dibandingkan jenis MOL lainnya (Batara, Anas, Santosa, \& Lestari, 2016). Menurut Parani dan Saha (2012), yang diperkuat Romero (2014) menyebutkan bahwa mikroorganisme selulolotik merupakan salah satu jenis mikroorganisme yang berperan dalam penyediaan unsur hara dan mengandung hormon pertumbuhan yang dibutuhkan oleh tanaman. Selanjutnya Mikroorganisme yang terkandung dalam MOL nasi yakni Sachhromycces cereviciae dan Aspergillus sp. yang merupakan agens antagonis terhadap banyak patogen tanaman (Royaeni, Pujiono, \& Pudjowati, 2014).

Menurut Purwasasmita (2009), larutan MOL mengandung unsur hara mikro dan makro dan juga mengandung bakteri yang menguntungkan sehingga dapat digunakan baik sebagai pendekomposer, pupuk hayati, dan pestisida organik. Selain itu, MOL juga mengandung hormon tumbuh seperti giberelin, sitokinin, dan auksin yang berfungsi sebagai zat perangsang tumbuh tanaman.

Berdasarkan analisis situasi di atas dapat dikatakan bahwa desa Pudak mempunyai potensi yang cukup besar untuk dikembangkan baik dari segi sumber daya manusia (SDM) maupun sumber daya alam (SDA). Namun sampai saat ini kedua potensi tersebut belum benar-benar diberdayakan, masih banyak lahan-lahan kosong yang belum termanfaatkan secara maksimal sebagai mana dapat dilihat pada Gambar 1. 


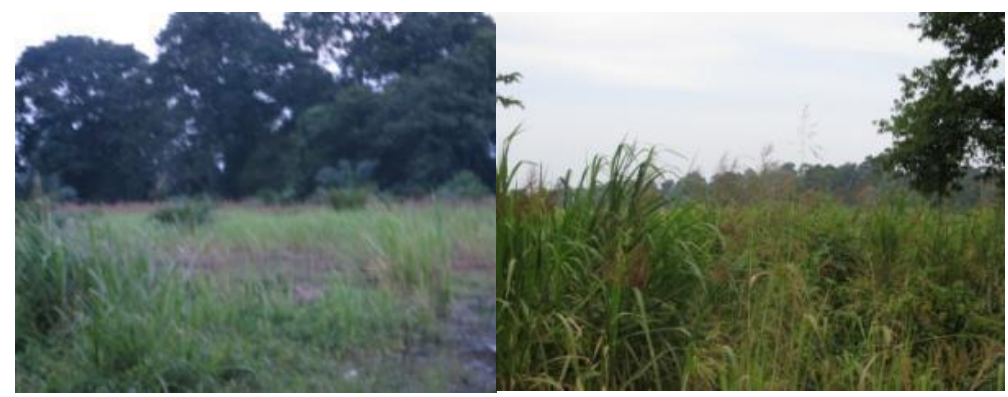

Gambar 1. Lahan Terlantar

Dari beberapa permasalahan di atas maka kami berusaha membantu mencarikan solusi agar masyarakat desa Pudak khususnya petani untuk memecahkan permasalahannya dengan membantu memberikan ilmu dan teknologi tentang pembuatan pupuk cair organik MOL (Mikro Organisme Lokal) dari sampah rumah tangga berupa sisa nasi dan sisa sayuran. MOL ini sangat diperlukan bagi petani untuk meningkatkan hasil pertaniannya. Disamping itu produk MOL ini dapat dijual untuk menambah pendapatan petani dan masyarakat pada umumnya.

\section{METODE PELAKSANAAN}

MOL (Mikro Organisme Lokal) adalah larutan hasil fermentasi yang berbahan dasar dari berbagai sumber daya yang tersedia setempat yang dapat digunakan sebagai pupuk cair. Pupuk cair MOL ini mengandung unsur hara mikro dan makro dan juga mengandung bakteri yang berpotensi sebagai perombak bahan organik, perangsang pertumbuhan, dan sebagai agens pengendali hama dan penyakit tanaman, sehingga MOL dapat digunakan baik sebagai dekomposer, pupuk hayati dan sebagai pestisida organik terutama sebagai fungisida. Pupuk cair MOL dibuat sangat sederhana yaitu dengan memanfaatkan limbah dari rumah tangga atau tanaman di sekitar lingkungan misalnya sisa-sisa tanaman seperti bonggol pisang, gedebong pisang, buah nanas, jerami padi, sisa sayuran, nasi basi, dan lain-lain. Bahan utama dalam larutan MOL terdiri dari 3 jenis komponen, antara lain:

1) Karbohidrat: air cucian beras, nasi bekas, singkong, kentang dan gandum;

2) Glukosa: cairan gula merah, cairan gula pasir, air kelapa/nira dan;

3) Sumber bakteri: keong mas, buah-buahan misalnya tomat, pepaya, dan kotoran hewan (Purwasasmita, 2009).

Menurut Handoko S., (2005) Keunggulan utama penggunaan MOL adalah murah bahkan tanpa biaya, selain itu ada beberapa keuntungan: 1) Mendukung pertanian ramah lingkungan; 2) Dapat mengatasi permasalahan pencemaran limbah pertanian dan limbah rumah tangga; 3) Pembuatan serta aplikasinya mudah dilakukan; 4) Mengandung unsur kompleks dan mikroba yang bermanfaat dalam produk pupuk dan dekomposer organik yang dihasilkan; 5) Memperkaya keanekaragaman biota tanah; dan 6) Memperbaiki kualitas tanah dan tanaman

Pada program pengabdian ini diterapkan cara pembuatan pupuk organik cair yang berasal dari sampah rumah tangga berupa sisa nasi, sisa sayuran, dan sisa ikan/udang. Pemakaian pupuk organik cair (MOL) ini akan dicobakan pada ladang yang sebagian 
besar lahan tersebut yang tidak dimanfaatkan oleh kelompok tani. Aplikasi penggunaan MOL sebagai pupuk organik akan dipakai pada setiap jenis tanaman yang ditanam dengan sistem organik pada ladang/huma. Dengan menggunakan sistem organik petani harus berani merubah kebiasaan bertanam tanaman secara konvensional kepada sistem organik yang jauh lebih hemat dan produktif.

Program pengabdian ini akan dilaksanakan di Desa Pudak, Kecamatan Kumpeh Ulu, Kabupaten Muaro Jambi. Pada program pengabdian ini akan dilakukan penyuluhan, dan demontrasi pembuatan pupuk cair MOL dari sampah rumah tangga berupa sisa nasi, sisa sayuran dan sisa ikan+udang. Aplikasi penggunaan MOL sebagai pupuk organik cair akan dipakai pada tanaman yang ditanam dengan sistem organik pada ladang/humo. Dengan menggunakan sistem organik petani harus berani merubah kebiasaan bertanam tanaman secara konvensional kepada sistem organik yang jauh lebih hemat dan produktif.

\section{HASIL DAN PEMBAHASAN}

\section{Survei Lokasi Penelitian}

Survei lokasi awal dilakukan pada tanggal 16 Juli 2019 yang diikuti oleh wakil Tim pengabdian. Selanjutnya pertemuan awal dengan ketua kelompok tani USAHA SEPAKAT untuk membicarakan teknis pelaksanaan kegiatan pengabdian di desa pudak kecamatan kumpeh. Setelah itu Tim minta jadwal pertemuan dengan seluruh anggota kelompok tani untuk menetapkan jadwal/ tempat penyuluhan.

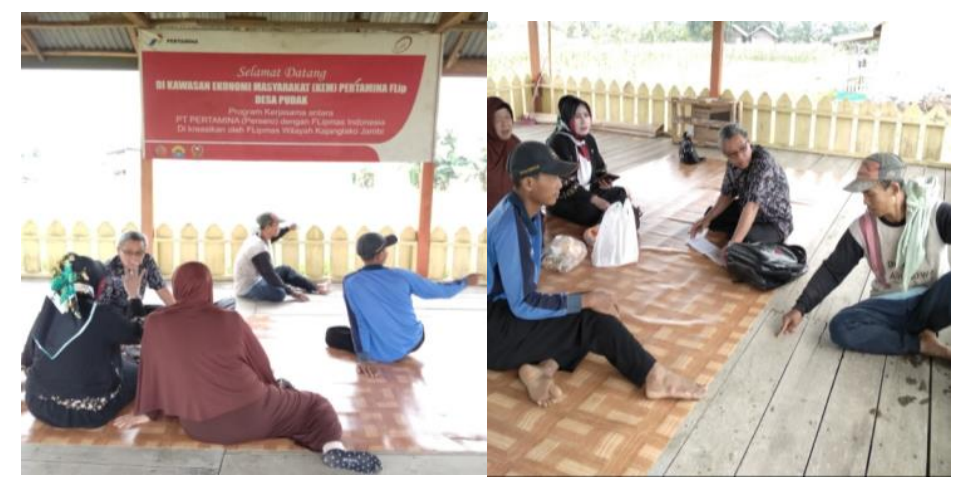

Gambar 1. Pertemuan Awal dengan Kelompok Tani

\section{Diskusi Dengan Ketua Kelompok Tani}

Diskusi tentang penentuan tanggal pelaksanaan Penyuluhan yang akan dihadiri lebih kurang 20 orang petani. Penyuluhan berupa penyampaian materi pengabdian "Pemanfaatan Sampah Rumah Tangga Menjadi Beberapa Jenis Pupuk Cair MOL (Mikro Organisme Lokal) di Desa Pudak Kecamatan Kumpeh Ulu Kabupaten Muara Jambi". 


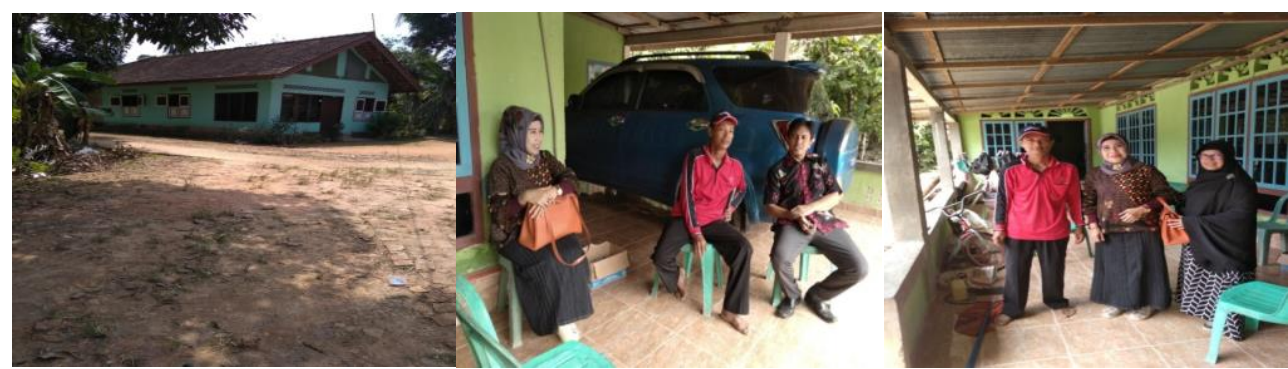

Gambar 2. Diskusi dengan Ketua kelompok Tani

\section{Pelaksanaan Penyuluhan}

Penyuluhan dilaksanakan tanggal 10 September 2019 dengan judul “.Pemanfaatan Sampah Rumah Tangga Menjadi Beberapa Jenis Pupuk Cair MOL (Mikro Organisme Lokal) di Desa Pudak Kecamatan Kumpeh Ulu Kabupaten Muara Jambi" jam 10.00-selesai di rumah Bapak Minto depan Kantor Camat Kumpeh Ulu diikuti oleh 25 orang peserta ibu-ibu rumah tangga. Adapun materi yang diberikan adalah:

\section{Prosedur Pembuatan MOL Sisa Nasi}

Salah satu limbah rumah tangga yang paling banyak diproduksi tiap harinya adalah nasi basi. Nasi basi dapat dimanfaatkan sebagai bahan pembuatan MOL untuk bioaktivator maupun pupuk hayati. Bahan yang digunakan adalah sebagai berikut: Nasi basi, secukupnya; Air; Gula pasir, 5 sendok makan

Cara Membuat:

1) Kepal-kepal nasi basi sebesar bola pingpong

2) Letakkan bola-bola nasi tersebut di dalam kardus, lalu tutup dengan dedaunan (misalnya daun pisang yang membusuk). Dalam jangka waktu 3 hari, akan tumbuh jamur-jamur berwarna kuning, jingga dan merah.

Cara Penggunaan:

1) Campurkan MOL nasi basi yang telah jadi dan air dengan komposisi 1: 5 liter, kemudian tambahkan gula 1 ons. Siramkan pada bahan organik (bahan baku kompos) yang akan dikomposkan

2) Penggunaan sebagai pupuk hayati: semprotkan pada tananam dengan konsentrasi larutan $400 \mathrm{cc}$ dicampur air sebanyak 14 liter.

\section{Prosedur Pembuatan MOL Sisa Sayuran}

Membuat MOL sisa sayuran memerlukan bahan-bahan, terdiri dari pucuk daundaun hijau segar, kotoran sapi, air kelapa, gula, dan tanah yang hidup. Adapun cara membuatnya, yaitu:

Pertama, siapkan tong plastik ukuran sedang, kira-kira volumenya 50 liter. Cuci sampai bersih supaya sisa-sisa zat kimia atau deterjen hilang, lalu tong dijemur supaya kering. Kedua, siapkan bahan-bahan yaitu pucuk daun apa saja yang berwarna hijau. Saya menggunakan daun papaya, daun tomat, daun teh-tehan, daun kiambang yang ada di sawah, eceng gondok, dan sejenisnya. Pilih daun-daun yang ada disekitar kita. Banyaknya sekitar $1 \mathrm{~kg}$, atau sekitar 1 kantong kresek plastik besar. Ketiga, siapkan kotoran sapi atau 
kotoran kambing atau kotoran ayam, sebanyak sekitar $1 \mathrm{~kg}$. Gula pasir sebanyak $1 / 2 \mathrm{~kg}$. Air kelapa gerlas 2 gelas minum. Keempat, siapkan tanah yang hidup, yaitu tanah selokan sebanyak $1 / 2 \mathrm{~kg}$. Upayakan tanah selokan ini tidak ada deterjen atau air sabun yang terbawa mengalir di selokan. Di dalam tanah selokan ini diharapkan banyak mikro organisme yang hidup. Kelima, setelah daun-daun hijau segar dipotong kecil-kecil, maka bersama bahan-bahan lain yang telah disiapkan, semuanya dimasukkan dalam tong plastik. Keenam, campurkan air sebanyak 40 liter. Diaduk hingga rata, kemudian tong ditutup dengan tutup yang berlubang-lubang supaya ada sirkulasi udara. Ketujuh, aduk tiap hari, setelah 5 hari pupuk cair ini bisa dimanfaatkan.

\section{Cara Penggunaan}

MOL atau mikro organisme lokal. Warnanya hijau, pekat, disebut MOL hijau. Baunya agak menyengat. Cara memanfaatkannya, ambil MOL hijau dari tong sebanyak 1 kaleng susu kecil. Masukkan dalam ember plastik, dan campurkan dengan air sebanyak 15 kaleng susu kecil. Aduk sampai rata, lalu siramkan pada media tanaman di pot atau di kebun rumah tangga kita. Menyiram MOL ke tanaman 3 hari sekali. Siramkan pada media tanahnya, bukan pada batang tanamannya.

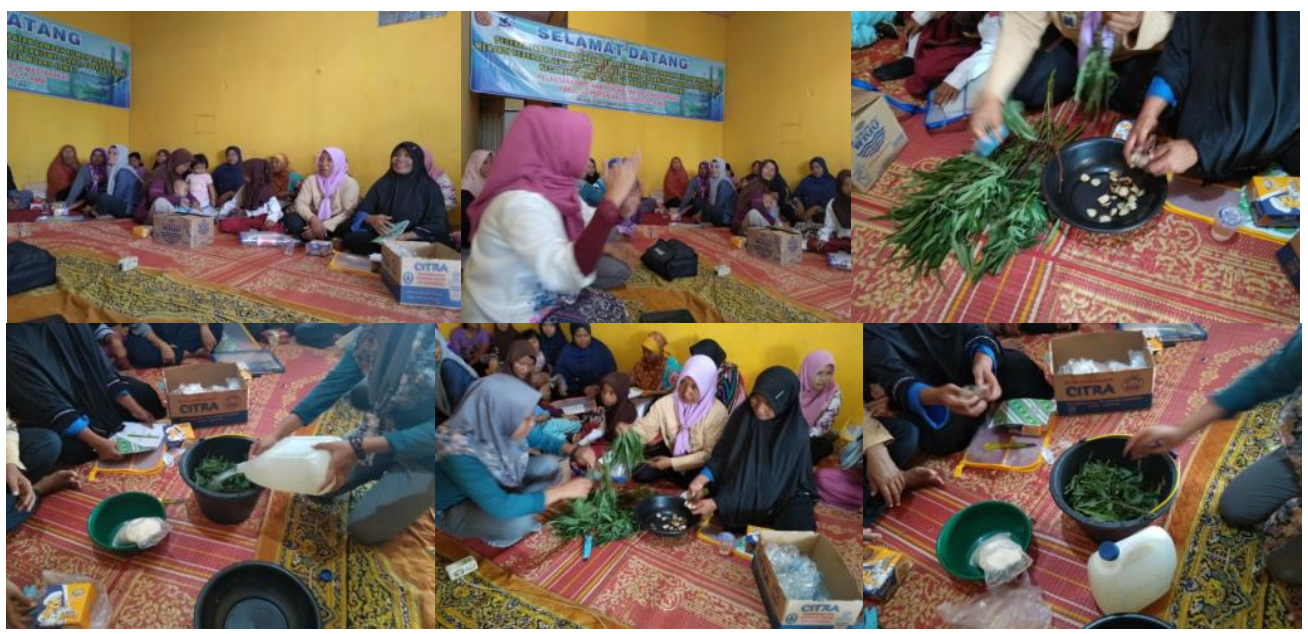

Gambar 3. Pelaksanaan Penyuluhan dan Demo Pembuatan MOL Sayuran

\section{SIMPULAN}

Program pengabdian ini menghasilkan output berupa: Pupuk Organik Cair MOL. Pembuatan pupuk Organik Mol hijauan dari sampah rumah tangga sangat banyak manfaatnya terutama untuk meningkatkan pertumbuhan dan produksi tanaman. Program pengabdian ini menghasilkan output berupa: pupuk organik MOL hijauan.

Pembuatan Pupuk Cair MOL berbahan dasar sampah rumah tangga berupa sisa nasi dan sisa sayuran/buah dilakukan dengan metode dan teknik yang sangat sederhana dan mudah dilakukan sendir oleh masyarakat petani, namun memiliki banyak manfaat terutama dalam menyediakan pupuk dan pestisida organik untuk budidaya pertanian, sekaligus juga dapat memelihara dan menjaga kebersihan lingkungan tempat tinggal.

Bertolak dari kegunaan dan prinsip ekologi, maka penggunaan pupuk cair MOL tersebut, bersifat ramah lingkungan, dan produk hasil panen yang dihasilkan tidak tercemar oleh bahan-bahan kimia yang membahayakan kesehatan dan lingkungan. 
Dengan demikian, kegiatan pengabdian ini mendukung kebijakan Pemerintah dalam rangka mewujudkan pembangunan berkelanjutan di bidang pertanian dengan menerapkan teknologi ramah lingkungan yang berbasis sumberdaya lokal, dan salah satunya adalah mengolah sampah rumah tangga menjadi Pupuk Cair MOL. Pupuk Cair MOL yang dihasilkan dapat menekan penggunaan pupuk kimia dan pestisida sintetis yang akhirnya dapat meningkatkan produktivitas tanah, mengurangi biaya produksi dan menghasilkan bahan pangan yang bebas bahan kimia sehingga bersih dan sehat untuk di konsumsi.

\section{UCAPAN TERIMA KASIH}

Penelitian ini didanai oleh Lembaga Penelitian dan Pengabdian (LPPM) Universitas Jambi, dari dana PNBP Fakultas Pertanian Universitas Jambi.

\section{REFERENSI}

Asandhi, A. A., Nurtika, N., \& Sumarni, N. (2005). Optimasi pupuk dalam usahatani LEISA bawang merah di dataran rendah. J. Hort 15(3), 199-207.

Batara, L. N., Anas, I., Santosa, D. A., \& Lestari, Y. (2016). Aplikasi mikroorganisme lokal (Mol) diperkaya mikrob berguna pada budidaya padi system of rice intensification (SRI) Organik. Jurnal Tanah dan Iklim, 40(1), 71-78.

Deptan. (2002). Agribisnis jagung: Informasi dan peluang. Bogor: Festival Jagung Pangan Pokok Alternatif.

Parani, K., \& Saha, B. K. (2012). Prospects of using phosphate solubilizing pseudomonas as bio fertilizer. European Journal of Biological Sciences, 4(2), 40-44.

Romero, E. S. (2014). Microbial fertilizers for increasing and sustaining rice production on organic area and area under conversion. International Journal of Scientific \& Technology Research, 3(8), 349-354.

Royaeni, R., Pujiono., \& Pudjowati, D. T. (2014). Pengaruh Penggunaan Bioaktivator MOL Nasi dan MOL Tapai Terhadap Lama Waktu Pengomposan Sampah Organik pada Tingkat Rumah Tangga. VISIKES: Jurnal Kesehatan Masyarakat, 13(1), 1-9.

RPJM Desa Pudak. (2012). Profil Desa Pudak, Kecamatan Jaluko, Kabupatren Muaro Jambi. Muaro Jambi: Pemerintah Desa Pudak.

Sutanto, R. (2002). Penerapan pertanian organik. Yogyakarta: Kanisius. 